\title{
EFFECT OF CONTROLLED MICRO-OXYGENATION ON WHITE WINE
}

\author{
EFEITO DA MICRO-OXIGENAÇÃO CONTROLADA NO VINHO BRANCO
}

\author{
Bozena Prusova*, Mojmir Baron \\ Department of Viticulture and Enology, Faculty of Horticulture, Mendel University in Brno, Valtická 337, CZ-691 44 Lednice, Czech Republic. \\ * Corresponding author: Tel.: +420-519-367-211, e-mail: prusova.bozena@email.cz
}

(Received 01.03.2018. Accepted 12.06.2018)

\section{SUMMARY}

The aim of the study was to determine the effect of controlled micro-oxygenation on the fermentation process of two types of white wine ('Pinot Blanc' and 'Pinot Gris'). The wine was micro-oxygenated during fermentation and maturation. During fermentation, the antioxidant activity was monitored by the DPPH method and the ammonia nitrogen and nitrogen content of the amino acids and the number of cells in $1 \mathrm{~mL}$ of fermenting must were also monitored. In micro-oxygenated wine, the growth of cell mass in the first third of the fermentation was recorded and showed an increase in ammonia nitrogen consumption compared to the control experiment. During fermentation, a slight increase in antioxidant activity was observed in the micro-oxygenated wine. For the aromatic profile measured by GC analysis, a higher content of aromatics, mainly esters, was observed in the micro-oxygenated wine. This was also present in the sensory evaluation.

\section{RESUMO}

Este estudo teve como objetivo a determinação do efeito da micro-oxigenação controlada no processo de ferementação de dois tipos de vinho branco ('Pinot Blanc' e 'Pinot Gris'). O vinho foi sujeito a micro-oxigenação durante a fermentação e a maturação. Durante a fermentação, foi monitorizada a atividade antioxidante através do método do DPPH, bem como o teor de azoto amoniacal, o teor de azoto dos aminoácidos e o número de células em $1 \mathrm{~mL}$ de mosto em fermentação. No vinho micro-oxigenado, foi registado o crescimento da massa celular no primeiro terço da fermentação, que evidenciou um aumento no consumo de azoto amoniacal relativamente ao controlo. Durante a fermentação, foi observado um ligeiro aumento da atividade antioxidante no vinho micro-oxigenado. No respeitante ao perfil aromático, determinado por cromatografia gasosa (GC), observou-se um teor superior de compostos aromáticos, principalmente ésteres, no vinho sujeito a micro-oxigenação. Efeito semelhante foi verificado na avaliação sensorial.

Key words: antioxidant activity, assimilable nitrogen, micro-oxygenation, white wine, yeast metabolism.

Palavras-chave: atividade antioxidante, azoto assimilável, micro-oxigenação, vinho branco, metabolismo das leveduras.

\section{INTRODUCTION}

The oxidation of wines has different consequences for red and white varieties, although the underlying chemistry is similar (Danilewicz, 2003; Waterhouse and Laurie, 2006). The key challenge of microoxygenation treatment (MOx) is to promote beneficial oxidation reactions while avoiding excessive oxidation that would spoil the wine. Therefore, one of the most important principles of micro-oxygenation treatment is that the rate of oxygen addition to wine is lower than the rate at which the oxygen is consumed through the chemical reactions (Jones et al., 1999;
Lemaire, 2002; Pour-Nikfardjam and Dykes, 2003; Calderón et al., 2014; del Álamo-Sanza and Nevares, 2014).

The oxygen absorptive capacity of a wine is determined by its total phenolic content as it is the phenolic compounds in wine that react with oxygen (Singleton, 1987). Different categories of phenolic compounds react differently with oxygen, however, and the total absorptive capacity of a wine depends on the rate of oxygen addition. The same wine could tolerate fairly large amounts of oxygen administered in small doses as the oxygen is slowly consumed

This is an Open Access article distributed under the terms of the Creative Commons Attribution License (http://creativecommons.org/licenses/by/4.0), which permits unrestricted use, distribution, and reproduction in any medium, provided the original work is properly cited. 
through reactions with phenols. Slow oxygen-induced polymerisation reactions are implicated in the positive changes associated with wine ageing (Fulcrand et al., 2006; Ribéreau-Gayon et al., 2006a) and it is these

types of reactions that micro-oxygenation seeks to induce (Lemaire, 2002; Bautista-Ortín et al., 2007; Nevares et al., 2017). A wine's ability to consume oxygen is also influenced by other factors, such as the availability of alternative substrates, antioxidants, and oxidation catalysts, e.g. $\mathrm{SO}_{2}$ and ascorbic acid, while metal ions in wine act as important catalysts of oxidation reactions (du Toit et al., 2006; Danilewicz, 2007; de Basquiat, 2008). Yeast lees also have a very high oxygen absorptive capacity; therefore, the presence of lees significantly increases a wine's ability to consume oxygen (Fornairon- Bonnefond and Salmon, 2003; Salmon, 2006; Mazauric and Salmon, 2006).

One of the benefits of the micro-oxygenation of white wines is the decrease in sulphide aromas associated with reduction. Many of the malodorous reductive sulphur compounds are extremely resistant to all corrective efforts and treatments, therefore, the problems can be easily corrected by oxygenation (Ribéreau-Gayon et al., 2006a). Micro-oxygenation could also increase long-term oxidative stability, thus providing protection against later, more harmful oxidation (Parish et al., 2000). A related idea is that the use of micro-oxygenation could lower $\mathrm{SO}_{2}$ requirements in winemaking (Robinson, 2006; Theron, 2007). Micro-oxygenation also produces more complex wines than stainless steel tank production alone (Bird, 2005).

Micro-oxygenation is used in red wines to improve colour and mouthfeel, decrease herbaceous flavours, remove reductive sulphur flavours, prolong the ageing of lees, and improve alcoholic fermentation (Rieger, 2000). Improved alcoholic fermentation is connected to yeast metabolism during industrial alcoholic fermentations. When sluggish fermentation is suspected, oxygen is added to improve biomass synthesis and increase fermentation rates. This has been well studied during enological fermentations (Sablayrolles et al., 1996) and it has been found that oxygen addition is efficient only at the end of the cell growth phase. This type of addition requires only low levels of oxygen, estimated at $5-10 \mathrm{mg} / \mathrm{L}$ during enological fermentations (Sablayrolles and Barre, 1986).

In this study, the micro-oxygenation was applied during the fermentation and maturation of white wine. The amount of live yeast and antioxidant activity was observed during fermentation and the aromatic profile was determined for the final wine.

\section{MATERIAL AND METHODS}

\section{Design of wine micro-oxygenation}

Two varieties, 'Pinot Blanc' and 'Pinot Gris', were used in the experiment. After pressing and racking, the must of each variety was divided into two parts. One part was micro-oxygenated and the other was made using the classic procedure to act as a control. The fermentation and micro-oxygenation of each variant was carried out in $2500 \mathrm{~L}$ steel tanks. In our experiment, we followed the manufacturer's instructions for micro-oxygenation. Vin 02 (EVER s.r.l., Italy) was used as micro-oxygenation equipment. The first micro-oxygenation programme was started at the end of the first third of the fermentation process (end of the growth phase) for 26 days. The oxygen dose was $15 \mathrm{mg} / \mathrm{L} / \mathrm{month}$ at 12 $15{ }^{\circ} \mathrm{C}$. To determine yeast population, $20 \mathrm{~mL}$ samples were taken three times: before and after microoxygenation treatment and at the end of fermentation. To determine antioxidant activity and content of yeast assimilable nitrogen, $2 \mathrm{~mL}$ samples were taken approximately every second day and immediately frozen. Nutrition was applied gradually in two forms: DAP (diammonium phosphate) and complex yeast nutrition. The minimum amount of both was applied at the same time. All samples were taken in triplicate.

The second micro-oxygenation programme was started during the maturation stage of wine, i.e. after racking, for about 6 months. The oxygen dose was 4$5 \mathrm{mg} / \mathrm{L} / \mathrm{month}$ at $15^{\circ} \mathrm{C}$. During the maturation of the wine, sampling was not performed, and samples (1 L) of the finished wine were taken in triplicate after the end of the whole production process.

\section{Determination of total acidity}

The total acidity of the must was estimated in accordance with Reg. (EC) $\mathrm{n}^{\mathrm{o}} 128 / 2004$ in an automatic titrator (TitroLine easy, SI Analytics, Germany). Titrations were performed using a SenTix $21 \mathrm{pH}$ electrode with $\mathrm{NaOH}(0.1 \mathrm{~mol} / \mathrm{L})$ as the titration reagent. The samples $(10 \mathrm{~mL})$ were diluted with $10 \mathrm{~mL}$ of distilled water. Due to subsequent formalin titration, the samples were not titrated up to the usual $\mathrm{pH}$ value of 7.0, but up to the value of 8.0. At the end of the titration, the consumption of $\mathrm{NaOH}$ solution (in millilitres) was read on the titrator's display.This consumption was multiplied with the factor of $\mathrm{NaOH}$ solution used for the titration and with the coefficient 0.75 . The result of this multiplication was equal to the content of total acidity as equivalents of tartaric acid (in $\mathrm{g} / \mathrm{L}$ ). Five mililitres of formaldehyde solution was added to this neutralised solution. A decrease in $\mathrm{pH}$ was observed and titration with $\mathrm{NaOH}$ was continued again to $\mathrm{pH} 8$. 
From the consumption of $\mathrm{NaOH}$, the blank (which was performed initially with distilled water) was read off and the result was multiplied by the factor of $\mathrm{NaOH}$ and the coefficient 140 to calculate a concentration of total yeast-assimilable nitrogen (in $\mathrm{mg} / \mathrm{L})$.

\section{Determination of $\mathbf{p H}$}

The $\mathrm{pH}$ value of the must was estimated in an undiluted $20 \mathrm{~mL}$ must sample using a pHmeter, WTW pH 526, and a SenTix 21 pH electrode (WTW, Germany).

\section{Determination of live yeast number}

The amount of live yeast was determined by direct counting in a Burker chamber. The samples of fermented wine were diluted at ratios of 1:10 and 1:100 and were treated with methylene blue solution for easy differentiation of live and dead cells. The samples were pippetted onto a clean glass slide in the Burker chamber and placed under the microscope (Olympus CX 31) at 40x magnification. Seventy two fields were monitored and evaluated (Babikova, 2010). Determination was carried out immediately in triplicate in $20 \mathrm{~mL}$ samples, which were taken before micro-oxygenation, after micro-oxygenation, and at the end of fermentation.

\section{Determination of alpha-amino nitrogen}

The primary amino groups are derivatised by $O$ phtaldialdehyde and N-acetyl-L-cysteine (OPA/NAC) to form isoindoles on the basic medium. These derivates were detected spectrophotometrically at 340 $\mathrm{nm}$. The absorbance was proportional to the amount of primary amino nitrogen in the sample. Yeast nonassimilable amino nitrogen (e.g. acylated or blocked amines, proline, and hydroxyproline) and ammonia nitrogen were not detected in this reaction. YANC (yeast assimilable nitrogen compounds) determination therefore required independent assays of primary amino nitrogen and ammonia nitrogen. The analysis was performed using a Miura one ${ }^{\circledR}$ device (I.S.E. S.r.1. Via Luigi Einaudi, Italy), which is a spectrophotometer equipped with an autosampler (Peynaud, 1984; Daudt et al., 1992; OIV, 2008). Determination was performed in triplicate in $2 \mathrm{~mL}$ samples that were taken during the fermentation process and immediately frozen.

\section{Determination of ammonia nitrogen}

The enzyme glutamate dehydrogenase (GLDH) catalyses the condensation of ammonia and $\alpha$ chetoglutarate to L-glutamate with the concomitant oxidation of nicotinamide adenine dinucleotide (NADH) - Equation 1.

$\mathrm{NH}_{3}+\alpha$-chetoglutarate $+\mathrm{NADH}+\mathrm{H}^{(\mathrm{GLDH})} \rightarrow$ L-Glutamate $+\mathrm{NAD}^{+}$Eq. 1
The oxidation of $\mathrm{NADH}$ causes a decrease in absorbance at $340 \mathrm{~nm}$, which is proportional to the amount of ammonia in the sample. The analysis was performed using a Miura one ${ }^{\circledR}$ device (I.S.E. S.r.1. Via Luigi Einaudi, Italy), which is a spectrophotometer equipped with an autosampler (Bergmeyer, 1974; Peynaud, 1984; OIV, 2008). Determination was performed in triplicate in $2 \mathrm{~mL}$ samples that were taken during the fermentation process and immediately frozen.

\section{Determination of antioxidant activity}

During the fermentation process, the values of the antioxidant activity were observed. The determination procedure was described earlier (Sochor et al., 2010). During this procedure, a $150 \mu \mathrm{L}$ volume of the reagent (0.095 mM 2,2-diphenyl-1-picrylhydrazyl, $\left.\mathrm{DPPH}^{\circ}\right)$ was incubated with $15 \mu \mathrm{L}$ of the wine samples. The absorbance was measured at $505 \mathrm{~nm}$ for 10 minutes and the output ratio was calculated as a difference between the absorbance values measured at the $10^{\text {th }}$ minute and the $2^{\text {nd }}$ minute of the assay procedure (Carmona-Jiménez et al., 2014). Determination was performed in triplicate in $2 \mathrm{~mL}$ samples that were taken during the fermentation process and immediately frozen.

\section{Determination of aromatic profile}

The concentration of the individual volatile compounds in the wine was determined according to the unpublished method of extraction with methyl-tbutylether (MTBE). Twenty millilitres of wine was pippetted into a $25-\mathrm{mL}$ volumetric flaskwith $50 \mu \mathrm{L}$ of 2-nonanol solution in ethanol. This compound was used as an internal standard (in a concentration of 400 $\mathrm{mg} / \mathrm{L})$ and $5 \mathrm{~mL}$ of a saturated $\left(\mathrm{NH}_{4}\right)_{2} \mathrm{SO}_{4}$ solution. The flask content was thoroughly stirred and $0.75 \mathrm{~mL}$ of the extraction solvent (MTBE with an addition of $1 \%$ cyclohexane) was then added. After another thorough stirring and the separation of individual phases, the upper organic layer was placed into a micro test tube together with the produced emulsion centrifuged and the clear organic phase was dried over anhydrous magnesium sulphate prior to the GCMS analysis. The extraction and subsequent GC analysis was performed three times. The average values and standard deviations were determined using Excel and Statistica 10.

Determination was performed in GC Shimadzu (GC$17 \mathrm{~A}$ ), equipped with an autosampler $\mathrm{AOC}-5000$ and connected to a QP detector (QP-5050A). Identification was performed using software GCsolution (program LabSolutions, version 1.20). Analysis was performed under the following conditions of separation: column: DB-WAX $30 \mathrm{~m} \mathrm{x}$ 
$0.25 \mathrm{~mm} ; 0.25 \mu \mathrm{m}$ stationary phase (polyethylene glycol). Voltage of the detector was $1.5 \mathrm{kV}$. Sample injection volume was $1 \mu \mathrm{L}$, with split ratio1:5. Flow of the carrier gas He was $1 \mathrm{~mL} / \mathrm{min}$ (linear gas velocity $36 \mathrm{~cm} / \mathrm{s}$ ), the temperature of the injection port was $180{ }^{\circ} \mathrm{C}$. Initial column temperature was 45 ${ }^{\circ} \mathrm{C}$ maintained for 3.5 minutes, followed by temperature gradient: to $75{ }^{\circ} \mathrm{C}$ gradient $6{ }^{\circ} \mathrm{C} / \mathrm{min}$; to $126{ }^{\circ} \mathrm{C}$ gradient $3{ }^{\circ} \mathrm{C} / \mathrm{min}$; to $190{ }^{\circ} \mathrm{C}$ gradient 4 ${ }^{\circ} \mathrm{C} / \mathrm{min}$; to $250{ }^{\circ} \mathrm{C}$ gradient $5{ }^{\circ} \mathrm{C} / \mathrm{min}$. Final temperature was maintained for the subsequent 6.5 min. Total length of analyses was 60 minutes. The detector worked in SCAN mode with interval $0.25 \mathrm{~s}$ in range 14-264. Individual compounds were identified by comparison of the MS spectrum and the retention time with the NIST 107 library.

For quantification, five-point calibration curves were constructed for all standard compounds containing the internal standard 2-nonanol. A synthetic wine model sample (12\% ethanol and $4 \mathrm{~g} / \mathrm{L}$ tartaric acid with $\mathrm{pH}$ 3.4 , adjusted by sodium hydroxide solution) was prepared for this purpose. This sample contained known amounts of the standards, which were extracted and analyzed by GC-MS as mentioned above. The extraction of volatile compounds was performed three times for each wine and then each extract was injected into the GC/MS. In order to quantify the volatile compounds present in the wines, the relative peak area (in the total ion chromatogram) of each analyte from the wine to the internal standard was compared to those obtained for the standards, taking into account the dilution of the samples. The concentration of the volatile compounds for which there was no pure reference was obtained using the calibration curve of one of the standard compounds with the most similar chemical structure, i.e. belonging to the same class of compounds.

The recovery of the method was established by spiking a wine sample with a standard working solution at three concentrations and assaying it in triplicate. The concentrations of the volatile compounds in the nonspiked wine were subtracted from the concentrations in the spiked wine and the recovery percentages $(R \%)$ were calculated by dividing the calculated concentrations by the expected concentrations. Calibration regression lines for each compound and the recovery percentage after the extraction process are shown in Table I.

\section{Sensory evaluation}

Altogether, eight experts participated in the sensory evaluation. Wine samples were evaluated using the UIOE (International Union of Oenologists) 100-point scale system. The tasting room was designed to conduct sensory analyses in known and controlled conditions as described in the ISO 8589 standard. One sensory session with four samples of wine took place in the morning. The samples were presented to the panel blind, coded. The four wines were blind tasted in clear INAO glasses by eight qualified assessors (in accordance with the standards ISO 8586). The tasting score sheet used was that of OIVUIOE, which is recommended for still white wine tasting in wine competitions. There are four tasting criteria: visual, nose, taste and harmony. Each criterion has various descriptors assigned on a fivepoint discontinuous scale, differently weighted according to descriptors. The final rating, a score on 100 , is obtained by combining the score scales by descriptor for each assessor of a same jury. Then, the average of all the final ratings of a same jury for each wine is calculated.

\section{TABLE I}

Calibration regression lines for each compound and recovery percentage after the extraction process

Retas de regressão da calibração para cada composto e percentagem de recuperação após o processo de extração

\begin{tabular}{|c|c|c|c|}
\hline Compound & Units & $\begin{array}{l}\text { Factor converting the } \\
\text { peak area to } \\
\text { concentration (F) }\end{array}$ & Recovery (\%) \\
\hline Isoamylalcohol & $\mathrm{mg} / \mathrm{L}$ & $2.17 \mathrm{E}-09$ & 97.6 \\
\hline Isobutylalcohol & $\mathrm{mg} / \mathrm{L}$ & $1.72 \mathrm{E}-09$ & 98.3 \\
\hline 2-Phenylethanol & $\mathrm{mg} / \mathrm{L}$ & $2.89 \mathrm{E}-09$ & 101.5 \\
\hline 1-Propanol & $\mathrm{mg} / \mathrm{L}$ & $2.45 \mathrm{E}-09$ & 97.9 \\
\hline 1-Butanol & $\mu \mathrm{g} / \mathrm{L}$ & $2.01 \mathrm{E}-08$ & 99.4 \\
\hline 1-Hexanol & $\mu \mathrm{g} / \mathrm{L}$ & 2.42E-09 & 99.7 \\
\hline 2,3-Butandiol & $\mathrm{mg} / \mathrm{L}$ & $5.21 \mathrm{E}-09$ & 93.6 \\
\hline Butyric acid & $\mathrm{mg} / \mathrm{L}$ & $1.62 \mathrm{E}-08$ & 96.4 \\
\hline Isobutyric acid & $\mathrm{mg} / \mathrm{L}$ & $1.11 \mathrm{E}-08$ & 97.1 \\
\hline Isovaleric acid & $\mathrm{mg} / \mathrm{L}$ & $1.45 \mathrm{E}-08$ & 98.3 \\
\hline 2-Methylbutanoic acid & $\mathrm{mg} / \mathrm{L}$ & $1.50 \mathrm{E}-08$ & 97.8 \\
\hline Hexanoic acid & $\mathrm{mg} / \mathrm{L}$ & $3.21 \mathrm{E}-09$ & 99.2 \\
\hline Octanoic acid & $\mathrm{mg} / \mathrm{L}$ & 2.93E-09 & 98.7 \\
\hline Decanoic acid & $\mathrm{mg} / \mathrm{L}$ & $3.23 \mathrm{E}-09$ & 100.4 \\
\hline Dodecanoic acid & $\mu \mathrm{g} / \mathrm{L}$ & 4.22E-08 & 102.6 \\
\hline Ethyl acetate & $\mathrm{mg} / \mathrm{L}$ & $3.68 \mathrm{E}-09$ & 94.3 \\
\hline Ethyl butyrate & $\mu \mathrm{g} / \mathrm{L}$ & $1.74 \mathrm{E}-08$ & 96.5 \\
\hline Ethyl hexanoate & $\mu \mathrm{g} / \mathrm{L}$ & $2.80 \mathrm{E}-09$ & 102.3 \\
\hline Ethyl octanoate & $\mu \mathrm{g} / \mathrm{L}$ & $2.68 \mathrm{E}-09$ & 103.1 \\
\hline Ethyl decanoate & $\mu \mathrm{g} / \mathrm{L}$ & $1.60 \mathrm{E}-08$ & 101.5 \\
\hline Ethyl dodecanoate & $\mu \mathrm{g} / \mathrm{L}$ & $1.74 \mathrm{E}-08$ & 103.8 \\
\hline Ethyl lactate & $\mathrm{mg} / \mathrm{L}$ & 4.42E-09 & 95.4 \\
\hline Isoamyl acetate & $\mathrm{mg} / \mathrm{L}$ & 2.41E-09 & 99.5 \\
\hline 2-Phenylethyl acetate & $\mu \mathrm{g} / \mathrm{L}$ & $1.21 \mathrm{E}-08$ & 100.8 \\
\hline Isobutyl acetate & $\mu \mathrm{g} / \mathrm{L}$ & $4.58 \mathrm{E}-09$ & 98.5 \\
\hline 1-Hexyl acetate & $\mu \mathrm{g} / \mathrm{L}$ & $8.28 \mathrm{E}-09$ & 99.7 \\
\hline 1,1-Diethoxyethan & $\mu \mathrm{g} / \mathrm{L}$ & $1.94 \mathrm{E}-08$ & 97.5 \\
\hline
\end{tabular}

\section{Statistical analysis}

Statistical analyses and graphs were generated using Excel 2007 (Microsoft Office, USA) and Statistica 10 (Copyright (C) StatSoft). A t-pair test was used for statistical analysis within the same group (at the same sampling time, always MOx versus control sample). Results are expressed as mean \pm standard deviation. 
Statistically significant differences are indicated with a lower case letter according to the level of significance: $\mathrm{a}=\mathrm{p}<0.05 ; \mathrm{b}=\mathrm{p}<0.01 ; \mathrm{c}=\mathrm{p}<0.001$.

\section{RESULTS AND DISCUSSION}

A key measurement of this study was the determination of the number of cells to confirm improved fermentation. The possible disadvantages of micro-oxygenation are mentioned in the literature, but have not yet been confirmed. The results of the individual studies were not consistent regarding the effect of micro-oxygenation on wine and therefore on the health benefits of red wines (de Beer et al., 2008). The results of this study contradict the hypothesis that a reduction in health benefits is associated with antioxidant activity. The aromatic profile was determined to confirm the hypothesis of a positive influence on the quality of the final wine.

\section{Determination of basic analytical parameters}

Basic analytical parameters, such as sugar content, $\mathrm{pH}$, total acidity, and yeast assimilable nitrogen of the grape musts are presented in Table II.

\section{TABLE II}

Basic analytical parameters of grape musts

Parâmetros analíticos básicos dos mostos

\begin{tabular}{cccccc}
\hline Date of harvest & $\begin{array}{c}\text { Sugar content } \\
\left({ }^{\circ} \mathrm{NM}\right)\end{array}$ & $\mathbf{p H}$ & $\begin{array}{c}\text { Total acidity } \\
(\mathrm{g} / \mathrm{L})\end{array}$ & $\begin{array}{c}\text { Assimilable nitrogen } \\
(\mathrm{mg} / \mathrm{L})\end{array}$ \\
\hline Pinot Gris & 22.09 .2016 & 22.5 & 3.4 & 7.4 & 245.75 \\
Pinot Blanc & 11.10 .2016 & 21.4 & 2.8 & 10.0 & 339.12 \\
\hline
\end{tabular}

\section{Determination of the number of live cells in the fermenting must}

A study of Rosenfeld et al. (2003) showed that lipid synthesis and optimal growth of Saccharomyces cerevisiae during alcoholic fermentation requires about $5-7.5 \mathrm{mg} / \mathrm{L}$ of oxygen. These values are consistent with previous data obtained under enological conditions (Sablayrolles and Barre, 1986). Under anaerobic conditions, yeast growth normally requires added oxygen to synthesize lipids (Andreasen and Stier, 1953, 1954), which are essential for plasma membrane integrity. Yeast under anaerobiosis accumulates unmodified plant phytosterols (mainly in their esterified form) that can promote yeast growth and initial fermentative activity by acting as substitutes for ergosterol in the yeast membrane. In the absence of added oxygen, however, these plant sterols quickly perturb the yeast membrane properties by being the predominant sterols, leading to sluggish fermentation (Luparia et al., 2004).

Figure 1 shows the number of live yeast cells during fermentation. There was a significant increase in live yeast after the micro-oxygenation applied at the end of the growth phase, i.e. during the first third of fermentation. The samples for this experiment were taken before and after MOx treatment and then at the end of fermentation.

Arapitsas et al. (2012) focused on oxygen candidate biomarkers and found that Saccharomyces requires oxygen for tryptophan and proline metabolism. In their experiment, once alcoholic formation ended, the wine no longer offered an anaerobic environment as the micro-organisms stopped fermentation and oxidative or respiratory metabolism through the citric acid (TCA) cycle taking place. The addition of a small amount of oxygen should therefore enhance mitochondria TCA metabolism. Products of this metabolism are acetaldehyde and pyruvic acid, which are used in the formation of vitisin and ethyl-bridged anthocyanins-catechin derivatives, e.g. succinic acid, and through the $\alpha$-ketoglutarate path, i.e. argine and proline. The amino acid tryptophan and the carbohydrate raffinose are typical nutritional factors of this metabolic cycle (Guadalupe and Ayestarán, 2007). 

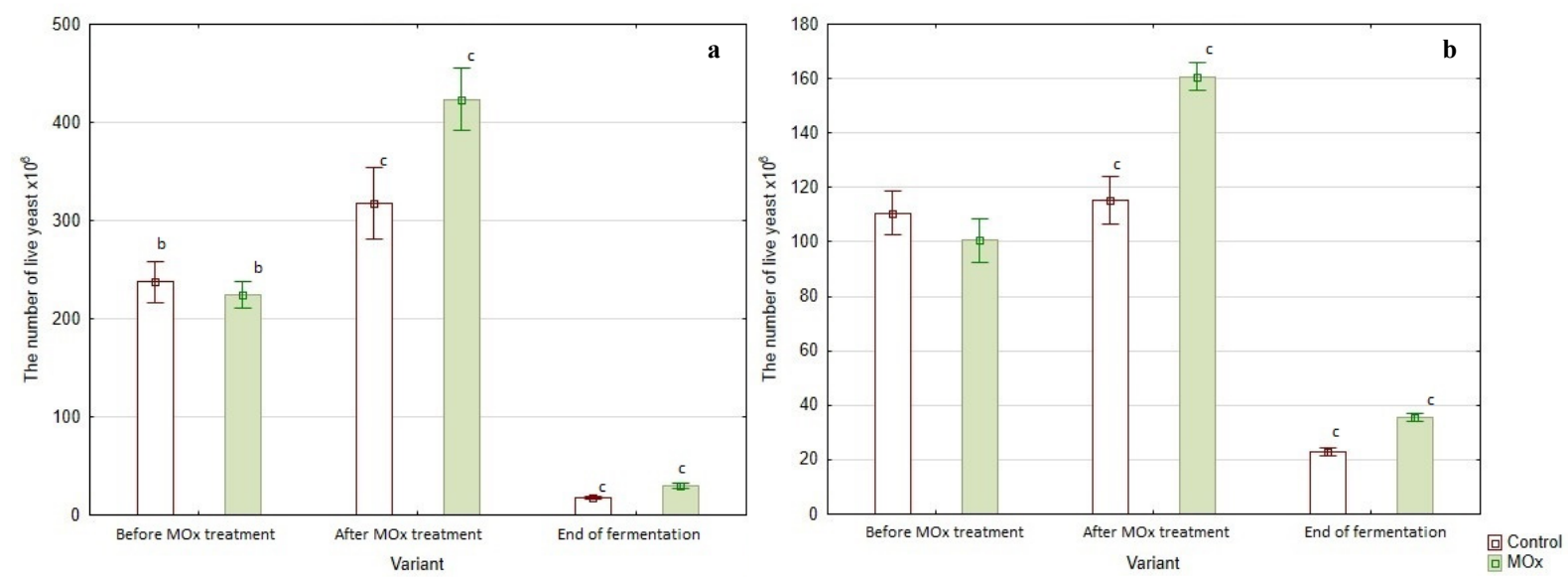

Figure 1. Number of live yeast in fermenting must of (a) 'Pinot Blanc' and (b) 'Pinot Gris'. The samples were taken before and after MOx treatment and at the end of fermentation. Statistically significant differences are indicated with a lower case letter according to the significance level: $\mathrm{a}=\mathrm{p}<0.05, \mathrm{~b}=\mathrm{p}<0.01, \mathrm{c}=\mathrm{p}<0.001$; the comparison is made within the same group (at the same sampling time; MOx versus control sample).

Número de celulas viáveis no mosto de (a) 'Pinot Blanc' e (b) 'Pinot Gris' em fermentação. As amostras foram recolhidas antes e após o tratamento de MOx e no final da fermentação. Diferenças estatísticamente significativas são indicadas com letras minúsculas, de acordo com o nível de significância: $a=p<0.05, b=p<0.01, c=p<0.001$; a comparação é feita dentro do grupo (em cada tempo de amostragem; MOx versus controlo).

In the absence of sugars, yeast can also use the glyoxylate cycle as a respiratory metabolism to synthesise sugars. An important intermediate for this path is succinate, which can also deliver succinic acid. Arginine is a basic amino acid. In an acidic medium such as wine, its guanidinium group has a positive charge that can easily be delocalised, enabling the formation of multiple double bonds and reactions with other active species. Moreover, arginine participates in reactions that generate the biogenic amines responsible for different wine defects. Further proof that these amino acids are involved in biosynthetic pathways under these conditions comes from the fact that Saccharomyces require oxygen for tryptophan and proline metabolism, while arginine can be metabolised in both aerobic and anaerobic conditions (Boulton et al., 1996; Ribéreau-Gayon et al., 2006b). Another benefit of micro-oxygenation for yeast metabolism during alcoholic fermentation is that it prevents stuck fermentations (Jones et al., 1999; Paul, 2002; Salmon, 2006).

\section{The nitrogen content in the ammonia and the} amino acids

The ammonia nitrogen content during fermentation is presented in Figure 2. The results of this study show higher consumption of ammonia in the microoxygenated wine, which is connected to the higher population of yeast. Yeast utilises ammonium nitrogen preferentially, which confirms the results shown in Figure 3. This figure illustrates the amino acid content during fermentation. The difference in the amino acids consumption was not significant. The initial ammonia and amino acid contents depicted as the first point in the graph. Two different nutrition types were used: DAP and complex yeast nutrition. The minimum amount of both was always added gradually at the same time. The additions are depicted as elevations of the curve.

As expected, the amino acids were used by the yeast during the growth phase for immediate production of protein or for storage for later biosynthetic needs. The amino acids were not taken up equally, however, with some utilised early in the growth cycle, some later, and others not at all or only to a limited extent. Furthermore, ammonia is normally present in must at levels ranging from 25 to near $200 \mathrm{mg} / \mathrm{L}$ and is consumed preferentially to amino acids (Fugelsang, 1997).

\section{Determination of antioxidant activity}

Figure 4 shows the results for the antioxidant activity determined during fermentation. There were no significant differences between the micro-oxygenated wine and the control. It means that all the oxygen added during fermentation was consumed by yeast and did not influence the chemistry of the wine. The antioxidant capacity of the micro-oxygenated wines has also been studied in red wines during wine maturation (Castellari et al., 2000; de Beer et al., 2008; Rivero-Perez et al., 2008) and the effect of micro-oxygenation on the antioxidant profile of these 
wines was found to be variety dependent (RiveroPerez et al., 2008). The controlled addition of oxygen to well-structured wines does not lead to significant changes in the antioxidant profiles. No differences were found between the control and the micro- oxygenated wines for antioxidant capacity or scavenger activity (Rivero-Perez et al., 2008), which contrasts with the findings of a few researchers.
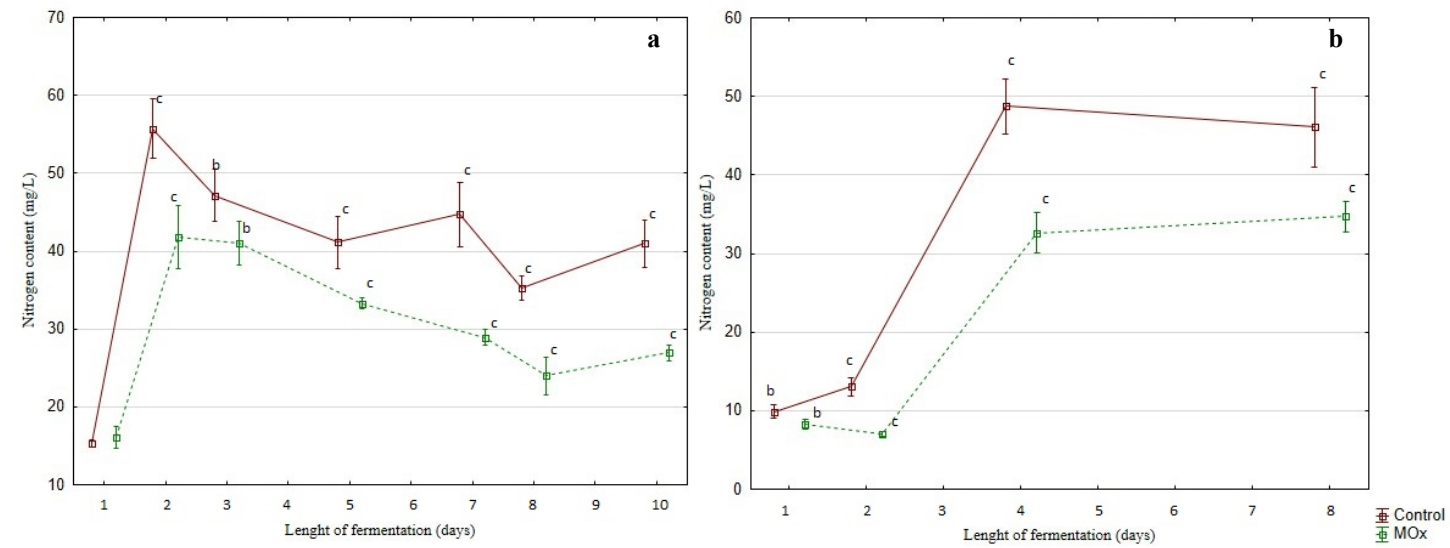

Figure 2. Nitrogen content in ammonia in fermenting must of (a) 'Pinot Blanc' and (b) 'Pinot Gris'.Statistically significant differences are indicated with a lower case letter according to the significance level: $\mathrm{a}=\mathrm{p}<0.05, \mathrm{~b}=\mathrm{p}<0.01, \mathrm{c}=\mathrm{p}<0.001$; the comparison is made within the same group (at the same sampling time; MOx versus control sample).

Teor de azoto amoniacal no mosto de (a) 'Pinot Blanc' $e$ (b) 'Pinot Gris' em fermentação. Diferenças estatísticamente significativas são indicadas com letras minúsculas, de acordo com o nível de significância: $a=p<0.05, b=p<0.01, c=p<0.001$; a comparação é feita dentro do grupo (em cada tempo de amostragem; MOx versus controlo).
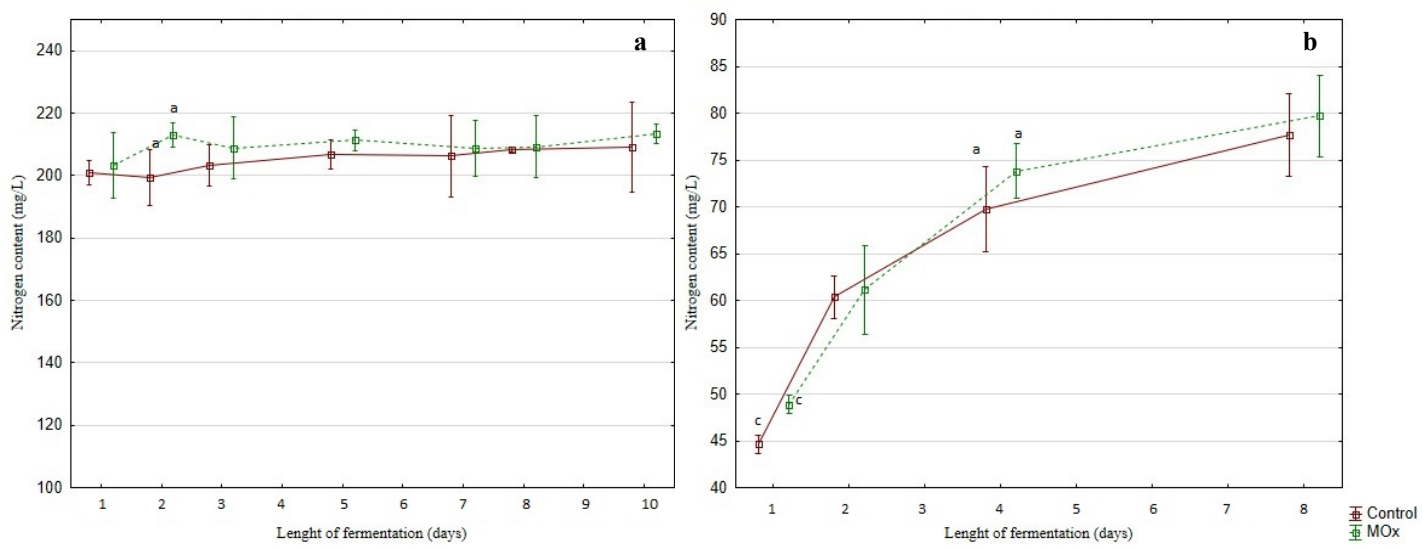

Figure 3. Nitrogen content in $\alpha$-amino acids in fermenting must of (a) 'Pinot Blanc' and (b) 'Pinot Gris'. Statistically significant differences are indicated with a lower case letter according to the significance level: $\mathrm{a}=\mathrm{p}<0.05, \mathrm{~b}=\mathrm{p}<0.01, \mathrm{c}=\mathrm{p}<0.001$, the comparison is made within the same group (at the same sampling time; MOx versus control sample).

Teor de azoto em $\alpha$-aminoácidos no mosto de (a) 'Pinot Blanc' e (b) 'Pinot Gris' em fermentação. Diferenças estatísticamente significativas são indicadas com letras minúsculas, de acordo com o nível de significância: $a=p<0.05, b=p<0.01, c=p<0.001$; a comparação é feita dentro do grupo (em cada tempo de amostragem; MOx versus controlo). 
Despite increased concentrations of gallic acid, especially in high-dose oxygenated wines, a decrease in the total antioxidant capacity of the wine has been observed (de Beer et al., 2008). Another study showed that the single bioactive phenolic compounds of wine decreased with oxygen addition (Castellari et al., 2000). The antioxidant activity in 'Pinot Blanc' and 'Pinot Gris' varieties evolves in the opposite direction. The reason for this could be different phenolic composition of each variety and therefore a different course of the polymerisation reaction during fermentation regardless of the amount of oxygen. The main phenolic compounds in wine include hydroxybenzoic acids, hydroxycinnamic acid derivatives, flavanols, flavonols, and anthocyanins. Differences in the phenolic content of grape cultivars and vinification techniques contribute to differences in the phenolic composition of wine and therefore in the antioxidant activity of wine (Macheix et al., 1990).
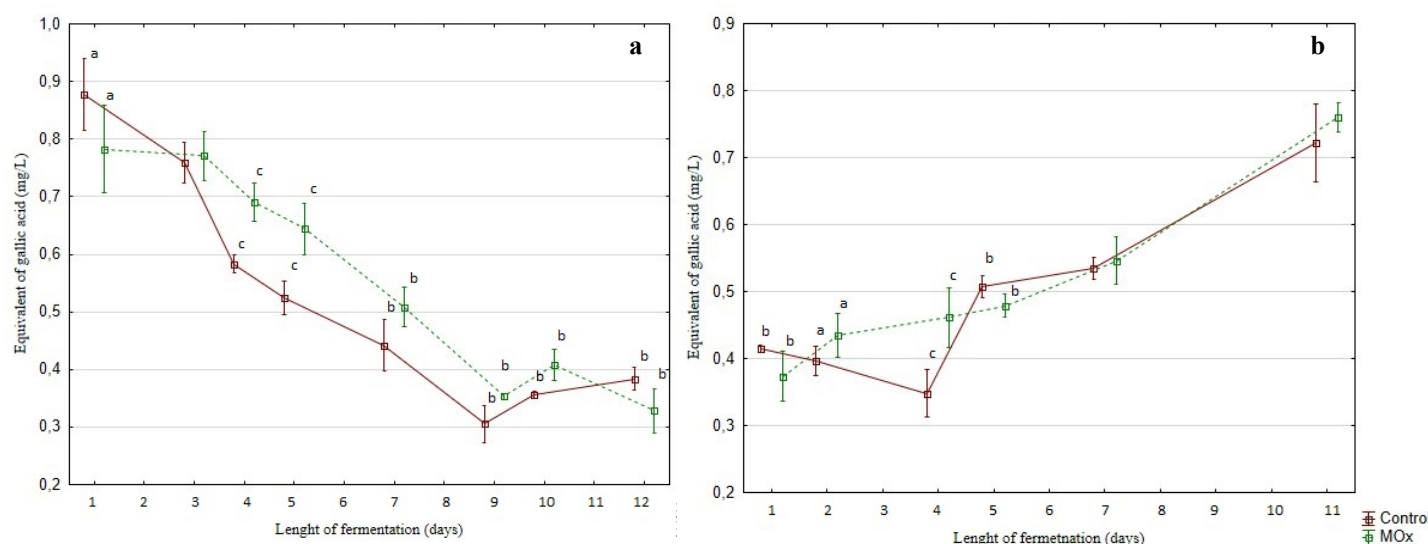

Figure 4. Antioxidant acitivity measured by DPPH method in (a) 'Pinot Blanc' and (b) 'Pinot Gris'. Statistically significant differences are indicated with a lower case letter according to the significance level: $a=p<0.05, b=p<0.01, c=p<0.001$; the comparison is made within the same group (at the same sampling time; MOx versus control sample).

Atividade antioxidante determinada pelo método do DPPH em (a) 'Pinot Blanc' e (b) 'Pinot Gris'. Diferenças estatísticamente significativas são indicadas com letras minúsculas, de acordo com o nível de significância: $a=p<0.05, b=p<0.01, c=p<0.001$; a comparação é feita dentro do grupo (em cada tempo de amostragem; MOx versus controlo).

\section{Determination of aromatic profile}

Higher alcohols, fatty acids, and esters were determined by gas chromatography. The results presented in Table III show higher determined values in the micro-oxygenated wine compared to the control. A t-test was used to analyse the volatile compounds and Table III contains the average of the three values, the standard deviations, and the t-test values.

The micro-oxygenated wine of the 'Pinot Gris' variety had a higher concentration of esters and higher alcohols and the aroma descriptors of selected esters are predominantly fruity and flowery. Higher concentrations of esters and higher alcohols were also observed in the 'Pinot Blanc' variety. The concentrations of ethyl butyrate, isoamylacetate, and 2-phenyl-ethylacetate, whose aroma descriptors are apricots, bananas, and flowers, respectively, were not significantly different. The concentrations of all other esters were significantly higher than concentration in control samples. 
Table III

Content of volatile compounds in 'Pinot Gris' and 'Pinot Blanc' wines

Teor de compostos voláteis nos vinhos 'Pinot Gris' e 'Pinot Blanc'

\begin{tabular}{|c|c|c|c|c|c|c|}
\hline \multirow[t]{2}{*}{ Compound } & \multicolumn{3}{|c|}{ Pinot Gris } & \multicolumn{3}{|c|}{ Pinot Blanc } \\
\hline & MOx & Control & $\mathbf{p}$ & MOx & Control & $\mathbf{p}$ \\
\hline Isoamylalcohol $(\mathrm{mg} / \mathrm{L})$ & $187.58 \pm 5.47$ & $140.02 \pm 3.66$ & $\mathrm{c}$ & $184.79 \pm 4.09$ & $133.44 \pm 1.67$ & $\mathrm{c}$ \\
\hline Isobutylalcohol $(\mathrm{mg} / \mathrm{L})$ & $27.86 \pm 0.63$ & $21.38 \pm 0.80$ & $\mathrm{c}$ & $18.48 \pm 0.61$ & $11.02 \pm 0.36$ & $\mathrm{c}$ \\
\hline 2-Phenylethanol (mg/L) & $5.83 \pm 0.23$ & $4.59 \pm 0.058$ & $\mathrm{c}$ & $6.92 \pm 0.06$ & $5.45 \pm 0.14$ & $\mathrm{c}$ \\
\hline 1-Propanol (mg/L) & $19.93 \pm 0.63$ & $12.99 \pm 0.21$ & $\mathrm{c}$ & $16.14 \pm 0.54$ & $10.01 \pm 0.40$ & $\mathrm{c}$ \\
\hline 1-Butanol $(\mu \mathrm{g} / \mathrm{L})$ & $705.59 \pm 26.57$ & $565.81 \pm 24.62$ & $\mathrm{~b}$ & $509.54 \pm 16.35$ & $288.36 \pm 5.83$ & $\mathrm{c}$ \\
\hline 1-Hexanol $(\mu \mathrm{g} / \mathrm{L})$ & $1215.65 \pm 51.06$ & $1083.06 \pm 29.98$ & a & $602.80 \pm 14.17$ & $384.46 \pm 16.27$ & $\mathrm{c}$ \\
\hline 2,3-Butandiol (mg/L) & $1071.76 \pm 21.97$ & $654.85 \pm 12.57$ & $\mathrm{c}$ & $972.47 \pm 14.91$ & $636.19 \pm 16.56$ & $\mathrm{c}$ \\
\hline Butyric acid (mg/L) & $1.23 \pm 0.05$ & $0.93 \pm 0.02$ & $\mathrm{~b}$ & $1.61 \pm 0.04$ & $1.25 \pm 0.03$ & $\mathrm{c}$ \\
\hline Isobutyric acid $(\mathrm{mg} / \mathrm{L})$ & $1.89 \pm 0.044$ & $1.51 \pm 0.046$ & $\mathrm{c}$ & $1.72 \pm 0.40$ & $1.23 \pm 0.06$ & $\mathrm{c}$ \\
\hline Isovaleric acid $(\mathrm{mg} / \mathrm{L})$ & $0.29 \pm 0.01$ & $0.22 \pm 0.01$ & $\mathrm{c}$ & $0.33 \pm 0.01$ & $0.27 \pm 0.01$ & $\mathrm{c}$ \\
\hline 2-Methylbutanoic acid (mg/L) & $0.23 \pm 0.003$ & $0.17 \pm 0.005$ & $\mathrm{c}$ & $0.16 \pm 0.01$ & $0.12 \pm 0.01$ & $\mathrm{c}$ \\
\hline Hexanoic acid (mg/L) & $4.21 \pm 0.13$ & $3.61 \pm 0.11$ & $\mathrm{~b}$ & $4.19 \pm 0.13$ & $3.48 \pm 0.15$ & $\mathrm{c}$ \\
\hline Octanoic acid (mg/L) & $4.23 \pm 0.02$ & $3.70 \pm 0.13$ & $\mathrm{~b}$ & $4.93 \pm 0.16$ & $4.60 \pm 0.13$ & \\
\hline Decanoic acid (mg/L) & $1.61 \pm 0.05$ & $1.5 \pm 0.01$ & a & $1.85 \pm 0.06$ & $1.79 \pm 0.04$ & \\
\hline Dodecanoic acid $(\mu \mathrm{g} / \mathrm{L})$ & $102.11 \pm 2.30$ & $60.65 \pm 0.82$ & $\mathrm{c}$ & $124.96 \pm 2.31$ & $106.43 \pm 1.60$ & $\mathrm{c}$ \\
\hline Ethyl acetate (mg/L) & $35.39 \pm 0.80$ & $27.88 \pm 0.81$ & $\mathrm{c}$ & $33.21 \pm 0.68$ & $36.09 \pm 1.17$ & $\mathrm{a}$ \\
\hline Ethyl butyrate $(\mu \mathrm{g} / \mathrm{L})$ & $347.69 \pm 10.90$ & $310.93 \pm 9.80$ & a & $332.10 \pm 6.69$ & $324.64 \pm 11.05$ & \\
\hline Ethyl hexanoate $(\mu \mathrm{g} / \mathrm{L})$ & $760.02 \pm 29.61$ & $538.13 \pm 15.95$ & $\mathrm{c}$ & $673.34 \pm 20.19$ & $491.19 \pm 20.52$ & $\mathrm{c}$ \\
\hline Ethyl octanoate $(\mu \mathrm{g} / \mathrm{L})$ & $905.70 \pm 40.32$ & $697.04 \pm 18.90$ & $\mathrm{~b}$ & $872.61 \pm 23.17$ & $748.94 \pm 14.92$ & $\mathrm{~b}$ \\
\hline Ethyl decanoate $(\mu \mathrm{g} / \mathrm{L})$ & $266.20 \pm 8.30$ & $140.96 \pm 3.80$ & $\mathrm{c}$ & $236.65 \pm 7.31$ & $179.94 \pm 6.09$ & $\mathrm{c}$ \\
\hline Ethyl dodecanoate $(\mu \mathrm{g} / \mathrm{L})$ & $20.17 \pm 0.60$ & $13.10 \pm 0.46$ & $\mathrm{c}$ & $15.95 \pm 0.17$ & $11.00 \pm 0.24$ & $\mathrm{c}$ \\
\hline Ethyl lactate (mg/L) & $11.18 \pm 0.44$ & $8.93 \pm 0.33$ & $\mathrm{~b}$ & $7.07 \pm 0.20$ & $3.91 \pm 0.06$ & $\mathrm{c}$ \\
\hline Isoamyl acetate $(\mathrm{mg} / \mathrm{L})$ & $4.02 \pm 0.13$ & $3.51 \pm 0.07$ & $\mathrm{~b}$ & $5.99 \pm 0.10$ & $6.10 \pm 0.22$ & \\
\hline 2-Phenylethyl acetate $(\mu \mathrm{g} / \mathrm{L})$ & $152.97 \pm 3.06$ & $116.62 \pm 3.90$ & $\mathrm{c}$ & $237 \pm 10.43$ & $237.49 \pm 8.11$ & \\
\hline Isobutyl acetate $(\mu \mathrm{g} / \mathrm{L})$ & $182.36 \pm 2.21$ & $158.47 \pm 3.68$ & $\mathrm{c}$ & $138.60 \pm 4.66$ & $113.49 \pm 3.81$ & $\mathrm{~b}$ \\
\hline 1-Hexyl acetate $(\mu \mathrm{g} / \mathrm{L})$ & $274.99 \pm 6.65$ & $212.24 \pm 5.21$ & $\mathrm{c}$ & $277.11 \pm 8.10$ & $249.83 \pm 1.66$ & $\mathrm{~b}$ \\
\hline 1,1-Diethoxyethan $(\mu \mathrm{g} / \mathrm{L})$ & $44.02 \pm 0.64$ & $1950.06 \pm 49.16$ & $\mathrm{c}$ & $2153.73 \pm 32.60$ & $2518.82 \pm 42.71$ & $\mathrm{c}$ \\
\hline
\end{tabular}

The higher contents of these volatile compounds may be connected to the higher content of yeast in fermented wine. The fatty acids, sterols, and lipids contained in yeast cells may be precursors of these volatile compounds. Studies investigating the effect of micro-oxygenation on the aromatic profile of wine show that micro-oxygenation affects wine aroma, but the effect depends to a large extent on the variety
(Hernández-Orte et al., 2009). McCord's research in 2003 also suggested that micro-oxygenation decreased sulphide reductive flavours (mercaptans), but this has not been confirmed in subsequent studies.

It is frequently claimed that micro-oxygenation is effective in decreasing vegetative and herbaceous flavours of wine (Parish et al., 2000; Paul, 2002; 
Blackburn, 2004). The origins of this claim are unclear as there is no obvious association between herbaceousness and reductive or oxidative conditions, but it may be linked to the notion that microoxygenation is successful in mitigating the effects of harsh green tannins. Two studies measured a large number of aroma compounds in wines treated with MOx (Hernández-Orte et al., 2009), but found no consistent increase in fruitiness or a decrease in green herbaceous flavours, which are the key claims of the industry. Also, both studies demonstrated that treated wines take up fewer wood compounds upon subsequent barrel maturation.

\section{Sensory evaluation}

Within the sensory analysis, the compared wine samples were evaluated and for both tested varieties, the micro-oxygenated wine achieved a higher average score than the non-micro-oxygenated wine. The average total point earnings were 75 ('Pinot Gris') and 82.3 ('Pinot Blanc') compared to their nonmicro-oxygenated variants: 70.3 ('Pinot Gris') and 79.6 ('Pinot Blanc'). For the 'Pinot Gris' variety, the difference was 4.7 points in favour of the microoxygenated variant and for the 'Pinot Blanc' variety it was 2.7 points. The evaluation as well as the difference between the micro-oxygenated and nonmicro-oxygenated variants within a given variety are illustrated in Figure 5.

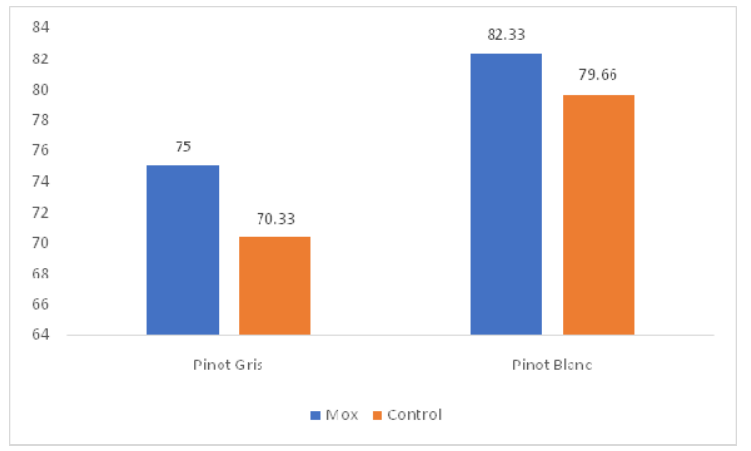

Figure 5. Results of the sensory evaluation.

Resultados da avaliação sensorial.

Only a few studies have included rigorous sensory testing by tasting panels. The results of these studies are also inconsistent. Some panels reported decreased

\section{REFERENCES}

Andreasen A.A., Stier T.J.B.,1953. Anaerobic nutrition of Saccharomyces cerevisiae. I. Ergosterol requirement for growth in a defined medium. J.Cell. Comp. Physiology, 41, 23-36. astringency after micro-oxygenation treatment, but several found no change, and at least one study found an increase in astringency (Pour-Nikfardjam and Dykes, 2003). The panel in Pour-Nikfardjam and Dykes'evaluation reported decreased herbaceous flavours in treated wines, but the sensory trials in the Hernández-Orteet al. (2009) study showed that herbaceous increased by micro-oxygenation. In keeping with their analysis of wood aroma compounds, their study also found that wood and toast flavours decreased in treated wine. Overall, a key concern in the current scientific literature is that treated wines are not always consistently preferred to non-treated wines.

\section{CONCLUSIONS}

The study of micro-oxygenation of white wines confirmed its contribution to the production of white wines. A significant increase in cellular mass was observed after micro-oxygenation at the end of the growth phase. Yeast mass has a positive effect not only on the fermentation process, but also on the final quality of the wine. Micro-oxygenated wines contained higher concentrations of esters and higher alcohols. Higher content of these volatile compounds is connected to a higher content of yeast in fermented wine. The fatty acids, sterols, and lipids, which are part of yeast cells, may be precursors to these volatile compounds. The increase in yeast was also confirmed by higher ammonia nitrogen consumption, whereas the consumption of nitrogen contained in amino acids was comparable. All the oxygen applied to fermenting must have been consumed by yeast metabolism. Antioxidant activity was not influenced by micro-oxygenation. In the sensory evaluation, the micro-oxygenated wines were also evaluated as being better than the controls. In conclusion, the use of controlled micro-oxygenation is relatively new and beneficial for the production of white wine.

\section{ACKNOWLEDGMENTS}

The financial support from sources of the project DG16P02R017 "Viticulture and Enology for maintaining and restoring cultural identity wine regions in Moravia" is highly acknowledged.

Andreasen A.A., Stier T.J.B.,1954 Anaerobic nutrition of Saccharomyces cerevisiae. II. Unsaturated fatty acid requirements for growth in a defined medium. J. Cell. Comp. Physiol., 43, 271281 . 
Arapitsas P., Scholz M., Vrhovsek U., Di Blasi S., Biondi Bartolini A., 2012. A Metabolomic Approach to the Study of Wine MicroOxygenation. PLOS ONE, 7, e37783.

Babikova P., 2010. Viticultural mikrobiology. 58 p. Mendel University, Brno.

Bautista-Ortín A.B., Fernández F.J.I., López-Roca J.M., GómezPlaza E., 2007.The effects of enological practices in anthocyanins, phenolic compounds and wine colour and their dependence on grape characteristics. J. Food Comp. Anal., 20, 546-552.

Bergmeyer H.U., 1974. Methods of Enzymatic Analysis, 112-117, Academic Press Inc., New York.

Bird D., 2005. Understanding wine technology. The science of wine explained. 263 p. DBQA Publishing, Newark.

Blackburn, D., 2004. Micro-oxygenation. Lessons from a decade of experience. Practical Winery \& Vineyard, March/April, 32-39.

Boulton R.B., Singleton V.L., Bisson L.F., Kunkee R.E., 1996. Principles and Practices of Winemaking. 604 p. Springer, New York.

Calderón J. F, del Álamo-Sanza M., Nevares I., Laurie V. F., 2014. The influence of selected winemaking equipment and operations on the concentration of dissolved oxygen in wines. Cienc. Investig. Agrar., 41, 273-280.

Carmona-Jiménez Y., García-Moreno M.V., Igartuburu J.M., Garcia Barroso C., 2014. Simplification of the DPPH assay for estimating the antioxidant activity of wine and wine by-products. Food Chem., 165, 198-204.

Castellari M., Matricardi L., Arfelli G., Galassi S., Amati A., 2000. Level of single bioactive phenolics in red wine as a function of the oxygen supplied during storage. Food Chem., 69, 61-67.

Danilewicz J.C., 2003. Review of reaction mechanisms of oxygen and proposed intermediate reduction products in wine: Central role of iron and cooper. Am. J. Enol. Vitic., 54, 73-85.

Danilewicz J.C., 2007. Interaction of sulfur dioxide, polyphenols and oxygen in a winemodel system: central role of iron and copper. Am. J. Enol. Vit., 58, 53-60.

Daudt C., Ough C., Stevens D., Herraiz T., 1992. Investigations into ethyl carbamate, N-propyl carbamate and urea in fortified wines. Am. J. Enol. Vit., 43, 318-322.

De Basquiat M., 2008. Oxygene et vin: Du role de l'oxygene a la technique de micro-oxygenation.7 p. Parsec S.r.1., Florence.

De Beer D., Joubert E., Marais J., Manley M., 2008. Effect of oxygenation during maturation on phenolic composition, total antioxidant capacity, colour and sensory quality of Pinotage wine. S. Afr. J. Enol. Vitic., 29, 13-25

del Álamo-Sanza M., Nevares I., 2014. Recent advances in the evaluation of the oxygen transfer rate in oak barrels. J Agric.Food Chem., 62, 8892-8899.

Du Toit W.J., Marais J., Pretorius I.S., 2006. Oxygen in must and wine: a review. S. Afr. J. Enol. Vitic., 27, 76-94.

Fornairon-Bonnefond C., Salmon J.M., 2003. Impact of oxygen consumption by yeast lees on the autolysis phenomenon during simulation of wine aging on lees. J. Agric.Food Chem., 51, 25842590 .

Fugelsang K.C., 1997. Wine Microbiology. 126 p. Springer Science \& Business Media, United States.

Fulcrand H.T., Dueñas M., Salas E., Cheynier V., 2006. Phenolic reactions during winemaking and aging. Am J Enol Vit, 57, 289297.
Guadalupe Z., Ayestarán B., 2007. Polysaccharide Profile and Content during the Vinification and Aging of Tempranillo Red Wines. J. Agric. Food Chem., 55, 10720-10728.

Hernández-Orte P., Cersosimo M., Loscos N., Cacho J., GarciaMoruno E., Ferreira V.,2009. Aroma development from non-floral grape precursors by wine lactic acid bacteria. Food Res. Int., 42, $773-781$.

ISO 8586, 2012. Sensory analysis -- General guidelines for the selection, training and monitoring of selected assessors and expert sensory assessors. Edition 1. 28 p. International Organization for Standardization, Geneva.

ISO 8589, 2007. Sensory analysis -- General guidance for the design of test rooms. Edition 2. 16 p. International Organization for Standardization, Geneva.

Jones G.P., Asenstorfer R.E., Iland P.G., Waters E.J., 1999. Colour, phenolics and tannins in wines. In: Proceedings of the Tenth Australian Wine Industry Technical Conference, Adelaide.

Lemaire T. 2002. Managing micro-oxygenation and other maturation techniques on a large scale: Fine tuning, away from the recipe. The example of Caves de Rauzna-Bordeaux wines. In: Proceedings of the ASVO Seminar 'Use of Gases in Winemaking', 54-59.

Luparia V., Soubeyrand V., Berges T., Julien A., Salmon J.M., 2004. Assimilation of grape phytosterols by Saccharomyces cerevisiae and their impact on enological fermentations. Appl. Microbiol. Biotechnol., 65, 25-32.

Macheix J.J., Fleuriet A., Billot J., 1990. Fruit Phenolics. 378 p. CRC Press, Boca Raton.

Mazauric J.P., Salmon J.M., 2006. Interactions between yeast lees and wine polyphenols during simulation of wine aging: II. Analysis of desorbed polyphenol compounds from yeast lees. J. Agric. Food Chem., 54, 3876-3881.

McCord J., 2003.Application of toasted oak and micro-oxygenation to ageing of cabernet sauvignon wines. Aust. N.Z. Grapegrow. Winemak., 474, 43-53.

Nevares I., Martínez-Martínez V., Martínez-Gil A., Martín R., Laurie V.F., del Álamo-Sanza M., 2017. On-line monitoring of oxygen as a method to qualify the oxygen consumption rate of wines. Food Chem., 229, 588-596.

OIV, 2008. Compendium of international methods of wine and must analysis, Vol. 1 and 2. International Organisation of Vine and Wine, Paris.

Parish M., Wollan D., Paul R., 2000. Micro-oxygenation - a review. Aust. N.Z. Grapegrow. Winemak., 438a, 47-50.

Paul R., 2002. Micro-oxygenation - Where now? In: Use of gases in winemaking. Proceedings of the Australian Society of Viticulture and Oenology Seminar, Adelaide.

Peynaud E., 1984. Knowing and making wine. 391 p. Wiley and Sons, New York.

Pour-Nikfardjam M.S., Dykes S.I., 2003. Micro-oxygenation research at Lincoln University. Part 3: Polyphenolic analysis of Cabernet Sauvignon. The Australian \& New Zealand Grapegrower \& Winemaker, 468, 41-44.

Regulation (EC) No. 128/2004. Amending Regulation (EEC) No 2676/90 determining Community methods for the analysis of wines, O.J.E.U., L19, 3-11.

Ribéreau-Gayon P., Glories Y., Maujean A., Dubourdieu D., 2006a. Chemical nature, origins and consequences of the main organoleptic defects. In: Handbook of Enology, 2. The chemistry of 
Arapitsas P., Scholz M., Vrhovsek U., Di Blasi S., Biondi Bartolini A., 2012. A Metabolomic Approach to the Study of Wine MicroOxygenation. PLOS ONE, 7, e37783.

Babikova P., 2010. Viticultural mikrobiology. 58 p. Mendel University, Brno.

Bautista-Ortín A.B., Fernández F.J.I., López-Roca J.M., GómezPlaza E., 2007.The effects of enological practices in anthocyanins, phenolic compounds and wine colour and their dependence on grape characteristics. J. Food Comp. Anal., 20, 546-552.

Bergmeyer H.U., 1974. Methods of Enzymatic Analysis, 112-117, Academic Press Inc., New York.

Bird D., 2005. Understanding wine technology. The science of wine explained. 263 p. DBQA Publishing, Newark.

Blackburn, D., 2004. Micro-oxygenation. Lessons from a decade of experience. Practical Winery \& Vineyard, March/April, 32-39.

Boulton R.B., Singleton V.L., Bisson L.F., Kunkee R.E., 1996. Principles and Practices of Winemaking. 604 p. Springer, New York.

Calderón J. F, del Álamo-Sanza M., Nevares I., Laurie V. F., 2014. The influence of selected winemaking equipment and operations on the concentration of dissolved oxygen in wines. Cienc. Investig. Agrar., 41, 273-280.

Carmona-Jiménez Y., García-Moreno M.V., Igartuburu J.M., Garcia Barroso C., 2014. Simplification of the DPPH assay for estimating the antioxidant activity of wine and wine by-products. Food Chem., 165, 198-204.

Castellari M., Matricardi L., Arfelli G., Galassi S., Amati A., 2000. Level of single bioactive phenolics in red wine as a function of the oxygen supplied during storage. Food Chem., 69, 61-67.

Danilewicz J.C., 2003. Review of reaction mechanisms of oxygen and proposed intermediate reduction products in wine: Central role of iron and cooper. Am. J. Enol. Vitic., 54, 73-85.

Danilewicz J.C., 2007. Interaction of sulfur dioxide, polyphenols and oxygen in a winemodel system: central role of iron and copper. Am. J. Enol. Vit., 58, 53-60.

Daudt C., Ough C., Stevens D., Herraiz T., 1992. Investigations into ethyl carbamate, N-propyl carbamate and urea in fortified wines. Am. J. Enol. Vit., 43, 318-322.

De Basquiat M., 2008. Oxygene et vin: Du role de l'oxygene a la technique de micro-oxygenation.7 p. Parsec S.r.1., Florence.

De Beer D., Joubert E., Marais J., Manley M., 2008. Effect of oxygenation during maturation on phenolic composition, total antioxidant capacity, colour and sensory quality of Pinotage wine. S. Afr. J. Enol. Vitic., 29, 13-25

del Álamo-Sanza M., Nevares I., 2014. Recent advances in the evaluation of the oxygen transfer rate in oak barrels. J Agric.Food Chem., 62, 8892-8899.

Du Toit W.J., Marais J., Pretorius I.S., 2006. Oxygen in must and wine: a review. S. Afr. J. Enol. Vitic., 27, 76-94.

Fornairon-Bonnefond C., Salmon J.M., 2003. Impact of oxygen consumption by yeast lees on the autolysis phenomenon during simulation of wine aging on lees. J. Agric.Food Chem., 51, 25842590 .

Fugelsang K.C., 1997. Wine Microbiology. 126 p. Springer Science \& Business Media, United States.

Fulcrand H.T., Dueñas M., Salas E., Cheynier V., 2006. Phenolic reactions during winemaking and aging. Am J Enol Vit, 57, 289297.
Guadalupe Z., Ayestarán B., 2007. Polysaccharide Profile and Content during the Vinification and Aging of Tempranillo Red Wines. J. Agric. Food Chem., 55, 10720-10728.

Hernández-Orte P., Cersosimo M., Loscos N., Cacho J., GarciaMoruno E., Ferreira V.,2009. Aroma development from non-floral grape precursors by wine lactic acid bacteria. Food Res. Int., 42, $773-781$.

ISO 8586, 2012. Sensory analysis -- General guidelines for the selection, training and monitoring of selected assessors and expert sensory assessors. Edition 1. 28 p. International Organization for Standardization, Geneva.

ISO 8589, 2007. Sensory analysis -- General guidance for the design of test rooms. Edition 2. 16 p. International Organization for Standardization, Geneva.

Jones G.P., Asenstorfer R.E., Iland P.G., Waters E.J., 1999. Colour, phenolics and tannins in wines. In: Proceedings of the Tenth Australian Wine Industry Technical Conference, Adelaide.

Lemaire T. 2002. Managing micro-oxygenation and other maturation techniques on a large scale: Fine tuning, away from the recipe. The example of Caves de Rauzna-Bordeaux wines. In: Proceedings of the ASVO Seminar 'Use of Gases in Winemaking', 54-59.

Luparia V., Soubeyrand V., Berges T., Julien A., Salmon J.M., 2004. Assimilation of grape phytosterols by Saccharomyces cerevisiae and their impact on enological fermentations. Appl. Microbiol. Biotechnol., 65, 25-32.

Macheix J.J., Fleuriet A., Billot J., 1990. Fruit Phenolics. 378 p. CRC Press, Boca Raton.

Mazauric J.P., Salmon J.M., 2006. Interactions between yeast lees and wine polyphenols during simulation of wine aging: II. Analysis of desorbed polyphenol compounds from yeast lees. J. Agric. Food Chem., 54, 3876-3881.

McCord J., 2003.Application of toasted oak and micro-oxygenation to ageing of cabernet sauvignon wines. Aust. N.Z. Grapegrow. Winemak., 474, 43-53.

Nevares I., Martínez-Martínez V., Martínez-Gil A., Martín R., Laurie V.F., del Álamo-Sanza M., 2017. On-line monitoring of oxygen as a method to qualify the oxygen consumption rate of wines. Food Chem., 229, 588-596.

OIV, 2008. Compendium of international methods of wine and must analysis, Vol. 1 and 2. International Organisation of Vine and Wine, Paris.

Parish M., Wollan D., Paul R., 2000. Micro-oxygenation - a review. Aust. N.Z. Grapegrow. Winemak., 438a, 47-50.

Paul R., 2002. Micro-oxygenation - Where now? In: Use of gases in winemaking. Proceedings of the Australian Society of Viticulture and Oenology Seminar, Adelaide.

Peynaud E., 1984. Knowing and making wine. 391 p. Wiley and Sons, New York.

Pour-Nikfardjam M.S., Dykes S.I., 2003. Micro-oxygenation research at Lincoln University. Part 3: Polyphenolic analysis of Cabernet Sauvignon. The Australian \& New Zealand Grapegrower \& Winemaker, 468, 41-44.

Regulation (EC) No. 128/2004. Amending Regulation (EEC) No 2676/90 determining Community methods for the analysis of wines, O.J.E.U., L19, 3-11.

Ribéreau-Gayon P., Glories Y., Maujean A., Dubourdieu D., 2006a. Chemical nature, origins and consequences of the main organoleptic defects. In: Handbook of Enology, 2. The chemistry of 